ってその基礎物が遊離して来ると，そこに，簡単な無 機化合物ができる。

（5）この無機化合物が再び上にのぼって，次の春に新し い循環が始まる。

最近の水不足に，こんなことを考えたのである。

\section{中川順 助}

择啓 今回『産業医学』特集号を発行なさるにつき, 何か執筆するよらにとの御手紙を頂き，恐入りました。

老生，住友別子病院に在勤中，貴協会の未席に㧤りま したが，昭和10年，停年退職後，当地（東京・世田谷） に転住，無為にすごしておりますので，格別申上げるよ らな感想もありませんのですから，何卒悪しからず御了 承の程覑上げます。

早々

(9月 4 日のはがき)

\section{思い出すままに}

\section{平松真 兵 衛}

世間の人は老人に対する敬意といらのか，あるいは尊 敬しての意味か，よく失礼ですが貴方は挑幾つですかと 聞かれることが䂺々ある。私は数年来というか，長い間 自分の年令を考えたこともなく，また，このような質問 を受けるのがイヤで，何時も問われたら，御想像に委す と逃げている。

この冊子を手にされる皆さんは，私が相当の老人であ ることは百も御承知のこと，それは名誉会員ということ 自体が私達の老歯であることを示しているからである。 しかし，私は自分の本来からの性格の現われともいらの か，茫然と手を拱いていることができない性格で，何か していないと落付かない。昭和 30 年頃から，知人の推䳡 で学校の衛生学の講義を受持っているが，大正 5 年，工 場法の実施から工場衛生の仕事に関与して以来，とさに 籍は多少転々としたが，この方面の仕事に対する興味は 忘れられない。ことに，昭和 22 年から実施された現労働 基準法の仕事に再び引き出されて参与し,これが一尿, 私 の労㗢衛生に対する関心を深める動機ともなったのであ る。しかし，労動基準法の仕事には自ら年柃の関係もあ って，昭和28年頃から一切手を引いたが，幸か不幸か， 今日学校に関係を持らながらも，もとの労働基準法に関 係をもった時代の友人なり，知人から，時々労衝衛生に 関する相談を受けるので，余睱をつくっては労働者の健
康管理の方面の仕事の手伝いに，時代湹れの者がと笑わ れても, 話の都度, 時間をつくって出かけては手を出す といら風に動いている。

昔から，知人やら友人は御承知のように，私はシャベ ルことは下手，また筆をとることも下手，害にとり得の ない人間である。今は既に故人であるが，我々の大先輩 石原修博士が，ある会談の席で私に，「筆を執ることの 上手下手を気にする必要はない。自分も筆を執ることは 上手でもない。従って，文章も下手だ。しかし，下手で も機会あるごとに畫いて和れば，意は自ら通ずで，人も 読んでくれる。なにも気に病む必要はないから書けよ」 との励ましの言葉を受けたのを覚えている。爾来, 先生 の言葉は忘れずに，下手の横好きとでもいうのか，機会 あるごとに書いている。それが次の題目のように七つば かりあるので，その論文の題だけならべて，老令でもま だ䮈尾に付して動いていることを示し，特笑いの種とし た次第である。

この論文は，いずれも学校の論䟾に掲載した。

1. 学生生徒の健康管理に関する調查

（月経と健康管理） 1956年 論欉 第 1 号

2. B C G接種亡ツ氏反応

1957年 I 第 2 号

3. 性格から見た運動（体育）と月経

1958年 " 第3号

4. B C G接種の特異体質から見たツ氏反応

1959年 " 第 4 号

5. 若年者の高血圧の問題に就て

1960年 / 第 5 号

6. 若年性高血生の成績調查

1962年 / 第6号

7. 工場の災害と月経に就て

1963年 I 第 7 号

偶 感

牧竟吉

やがて一昔にも近くなるが，本誌の読者各位の御記憶 にはまだ新しからうと思う。

近畿の某絹糸工場が争議に入って，永い間ごたついた ときのことである。当時の新聞には,殆ど連日,その経過 が報道され，某紙は財界，産業界の名士談を連載した。

その中で，ある知名の土が次のような所懐を述べて居 たのである。 